\title{
Effects of varying levels of fish oil on growth performance, body composition and haematological characteristics of Nile tilapia Oreochromis niloticus (L).
}

\author{
Midhat A. El-Kasheif ${ }^{1}$; Amal S.Saad ${ }^{1}$ and Seham A. Ibrahim ${ }^{2}$ \\ 1- National Institute of Oceanography and Fisheries, Cairo \\ 2- Faculty of Science, Benha University, Benha - Egypt
}

\begin{abstract}
$O$ reochromis niloticus with an average weight of 25.7 g.were reared in glass aquaria at a density of 15 fish / aquarium for a period of 16 weeks. Four artificial diets with control diet containing (0\%), 3\%, 6\% and 9\% supplemented fish oil were used in the present study, to investigate their effects on growth, body composition and haematological properties of Nile tilapia. Results revealed that the best growth $(54.4 \mathrm{~g} / \mathrm{fish})$ was obtained with the $9 \%$ supplementary lipid followed by the diets containing 3\% fish oil (48.7 g/fish), control diet (47.3 g/fish) and 6\% (41.1 g/fish) supplemented fish oil.

Furthermore, the highest percentage of weight gain $(28.7 \%)$ and the highest specific growth rate $(0.78 \%)$ were obtained with the $9 \%$ supplemented fish oil. Biochemical analysis of whole fish bodies indicated that moisture, ash and protein contents were unaffected by the lipid levels in the diet, lipid content was increased with the increased lipid level. Results of the present study show that serum cholesterol and glucose levels as well as haemoglobin content were affected significantly with the lipid levels. Total serum protein (TSP), total serum albumin (TSA) and total serum globulin (TSG) studied show that the (TSP) and (TSG) were not significantly ( $p>0.05$ ) affected by lipid levels, while the (TSA) was significantly $(\mathrm{p}<0.05)$ affected by lipid levels. Also results revealed that R.B.Cs, W.B.Cs counts, Hb and haematocrit (P.C.V) were not significantly affected by lipid levels among all treatments. Results of the experiment show that protein, glucose and cholesterol for fish fed diet containing the highest supplemented lipid (9\%) level were significantly different $(p<0.05)$. Based on the obtained results, it could be concluded that an artificial feed with $3 \%$ and $9 \%$ supplemented fish oil is sufficient for feeding O.niloticus without any adverse effects on growth performance, body composition and haematological properties.
\end{abstract}

Keywords: Lipid, growth, body composition, haematology, O. niloticus

\section{INTRODUCTION}

Aquaculture is recently playing an important role in the world fish production, and in 1990 it contributed about 10\% of the total world fish 
production (Tacon, 1993). Also aquaculture is one the fastest growing food production activities in the world (FAO, 1997). Tilapias are considered the most important farmed fish in Egypt, since they represent about 52.8\% of the total freshwater fish yield in Egypt (GAFRED, 1996). Fish oil is the main source of lipid used in the formulation of commercial aqua feeds, providing essential n-3 fatty acids. Recently, the consumption of fish oil in aqua feeds has been estimated to be 0.7 million tons, representing $60 \%$ of the global fish oil production, and within a decade the demand for fish oil for aqua feeds would exceed total available supplies (New and wijkstrom, 2002). It is well known in carnivorous fish that protein utilization can be improved by partially replacing protein with lipid NRC (National Research Council, 1993) and Kim and Lee, (2005). However, little information about the protein-sparing effect of dietary lipids is available for herbivorous fish. The digestibility of dietary lipid in fish is generally high. However, there are certain differences in digestibility of various fatty acids .In general, the apparent digestibility of fatty acids decreases with increasing fatty acid chain length and increases with increasing unsaturation of fatty acids (Ng et al., 2004 a ).

The importance of lipid as a main source of energy was studied by many authors (Halver, 1976; Winfree and Stickney, 1981; Viola et al., 1988 and Kheir, 1997). Adequate energy in the form of dietary lipid spare the protein to perform its function in building up tissues (Parazo, 1990). Also Brandt (1979) recorded that lipid can be used as a source of protein- sparing energy nutrient. Fatty acid composition of adipose lipid in fish is influenced primarily by diet, whereas membrane lipids are more characteristic of environment and species (Lovell, 1989). Protein sparing effects of dietary carbohydrate and lipid were examined for dextrin and Pollack liver oil and it was shown that these substances could be utilized as energy sources up to a certain level improving protein efficiency ratio (PER). However, effects on growth were not clarified (Takii et al., 1995).

Santiago and Reye (1993) studied the effects of dietary lipid source on the reproductive performance and tissue lipid of Nile tilapia. Pratoomyot et al. (2010) investigated the effects of high levels of replacement of dietary fish meal by mixtures of plant protein sources on growth performance, lipid composition, protein and lipid digestibility and fatty acid profile. Also Zheng et al. (2010) showed that the dietary lipid significantly affected survival and growth of dark barbel catfish larvae. Kowalska et al. (2010) recorded the high level of vegetable oils in the feed groups (linseed oils (Lo)/ peanut oils (Po) (Lo), fish oil (Fo)/ peanut oils linked to increase viscerosomatic index $(\mathrm{p}<0.05)$.

Blood parameters, serum composition and biochemical constituents are the most indicator of the general condition of the fish. Li et al.(2010) concluded that the nitrogen retention increased significantly as protein levels $(p<0.01)$ decreased and lipid levels $(\mathrm{p}<0.05)$ increased, contrary to moisture content, lipid content of whole body and carcass increased significantly $(\mathrm{p}<0.05)$ with increasing lipid levels. Abdel-Tawwab et al. (2009) reported that the 
haematological variables of Nile tilapia (Oreochromis niloticus) were significantly affected by protein level, fish weight, and their interaction except for serum lipids which was not significantly affected by the interaction.

The objective of the present study was to find out the sutiable lipid level for Oreochromis niloticus and to evaluate the effect of lipid level on the rate of growth, body composition and haematological characteristics.

\section{Site of work:}

\section{MATERIALS AND METHODS}

The experiments were conducted at the Faculty of Agriculture, El-Monfia University-Shabeen El-Koum city-Egypt.

\section{Experimental aquaria:}

Twelve glass aquaria, each of 35 liter volume were filled with dechlorinated tap water. The water in each aquarium was provided with sufficient aeration by means of an electric air compressor. Every day, before the common feeding faeces and other remains were removed by siphoning. Throughout the experiment, each aquarium was partially cleaned daily.

\section{Artificial diet:}

Four isonitrogenous diets (24.51to 25.27\%crude protein) (Table 1) were formulated to contain four lipid levels (6.0, 8.9, 11.79and 14.69\%).

Table 1: Composition of experimental diets /100 g with three lipid levels

\begin{tabular}{|l|l|c|c|c|}
\hline \multirow{2}{*}{ Ingredients } & \multirow{2}{*}{ Control } & \multicolumn{3}{c|}{ \% lipid in the diet } \\
\cline { 3 - 5 } & & $\mathbf{3 \%}$ & $\mathbf{6 \%}$ & $\mathbf{9 \%}$ \\
\hline Fish meal & 15.0 & 15.0 & 15.0 & 15.0 \\
\hline Ground nut cake & 20.0 & 20.0 & 20.0 & 20.0 \\
\hline Rice bran & 24.0 & 24.0 & 24.0 & 24.0 \\
\hline Maize yellow corn & 40.0 & 37.0 & 34.0 & 31.0 \\
\hline Vitamins \&minerals mix. & 1.0 & 1.0 & 1.0 & 1.0 \\
\hline Fish oil & 0.0 & 3.0 & 6.0 & 9.0 \\
\hline Total & 100 & 100 & 100 & 100 \\
\hline
\end{tabular}

Ingredients, proximate composition and gross energy of the experimental diets are shown in Table (2).

Control diet was not supplemented with fish oil and contained 6.0 \%lipid from feed ingredients, while the other three experimental diets contained three supplemental levels of fish oil (3\%, 6\%and 9\%). Chemical composition and energy values of the four experimental diets were determined according to NRC (1993), as shown in Table (2). Fry in each group of aquaria were fed on one of four diets. The artificial diets were offered to fish in dry pellet form, 6 days week at the rate of $3 \%$ of the total body weight of fish in each aquarium. 
Table 2: Chemical composition and energy values of the four experimental diets.

\begin{tabular}{|c|c|c|c|c|}
\hline \multirow[t]{2}{*}{ Component } & \multirow[t]{2}{*}{ Control } & \multicolumn{3}{|c|}{ Lipid level } \\
\hline & & $3 \%$ & $6 \%$ & $9 \%$ \\
\hline Dry matter & 89.39 & 86.75 & 84.00 & 81.47 \\
\hline Crude protein & 25.27 & 25.02 & 24.76 & 24.51 \\
\hline Crude lipid & 6.01 & 8.9 & 11.79 & 14.69 \\
\hline Crude fiber & 5.68 & 5.61 & 5.54 & 5.47 \\
\hline Ash & 7.77 & 7.73 & 7.69 & 7.65 \\
\hline Nitrogen free extract $^{1}$ & 45.17 & 39.49 & 34.33 & $29-15$ \\
\hline Metabolizable energy $^{2}(\mathrm{kcal} / \mathrm{Kg})$ & 12.99 & 13.13 & 13.34 & 13.55 \\
\hline Gross energy $^{3}(\mathrm{kcal} / \mathrm{kg})$ & 3849.06 & 3874.33 & 3920.4 & 3967.17 \\
\hline P/E (g.kcal-1) & 0.066 & 0.065 & 0.063 & 0.062 \\
\hline
\end{tabular}

1- Nitrogen free extract by difference

2- Metabolizable energy based on the standard physiological values of $18.8 \mathrm{k} \mathrm{j} / \mathrm{g}$ protein , $13.8 \mathrm{kj} / \mathrm{g}$ carbohydrate and $33.5 \mathrm{kj} / \mathrm{g}$ fat (Brett and Groves 1979 ).

3- Gross energy contents (Kcal / kg) according to NRC (1993) using following calorific values 5.64, 9.44 and $4.11 \mathrm{kcal} / \mathrm{Kg}$ whole body of protein, fat and carbohydrate respectively.

\section{Growth parameters:}

Fish length and weight in each aquarium were measured to nearest $0.1 \mathrm{~cm}$ and weighed to the nearest 0.1 g randomly every 15 days for a period of 16 week. The following equation was used to evaluate fish growth performance:

Weight gain = Mean final weight - Mean initial weight

The specific growth rate (SGR) in terms of dry weight was calculated by applying the following equation (Xie et al., 1997):

\section{$\mathrm{SGR}=100 \times(\mathrm{Ln}$ FBW-Ln IBW)/t}

Where FBW and IBW are the final and initial body weight in grams and $t$ is the period in days. The survival percentage of each group was determined according to Richardson et al. (1985). Feed conversion ratio (FCR) and (PER) were calculated according to Dato-Cajegas and Yakupitiyage (1996):

$$
\text { FCR = dry feed (g)/ weight gain (g) }
$$

PER=wet weight gain (g)/amount of protein fed (g)

At the experimental termination, seven fish from each aquarium were randomly collected for proximate analysis of the whole fish body. Moisture content was measured by drying the sample at $105^{\circ} \mathrm{C}$ to constant weight in an oven. Protein was calculated as $\mathrm{N} \times 6.25$ by Kjeldahl methods. Crude fat was estimated using Soxhlet apparatus with petroleum ether and ash by heating at $550^{\circ} \mathrm{C}$ for $24 \mathrm{~h}$ in ashing furnace.

To study the effects of different levels of lipid on some haematological parameters of Oreochromis nilotocus, blood was collected directly from the caudal artery into heparinized capillary tubes. Haemoglobin content was measured using Sahli haemometer system. Serum protein, albumin, cholesterol and glucose were measured using standard Kits (Modern Laboratory Kits). 


\section{Statistical analysis:}

Statistical analysis of data was computed by the analysis of variance and the least significant differences (LSD) between means according to Snedecor and Cochran (1982).

\section{RESULTS}

\section{Growth performance parameters:}

Growth parameters of Oreochromis niloticus are shown in Table (3). It is clear that fish fed on diet containing 9\% supplemented lipid attained a maximum of $54.4 \mathrm{~g} /$ fish final weight, while those fed on diets containing 3\% and 6\% reached 48.7 and $41.1 \mathrm{~g} /$ fish respectively and fish fed on control diet attained $47.3 \mathrm{~g} /$ fish at a period of four months. The statistical evaluation of results revealed that fish fed on diet containing 9\% fish oil had significantly $(\mathrm{P}<0.05)$ higher weight followed in a decreasing order $(\mathrm{P}<0.05)$ by the $3 \%$ and the control groups and the $6 \%$ oil group respectively.

Table 3: Growth performance and feed conversion ratio of Oreochromis niloticus as affected with levels of lipid.

\begin{tabular}{|l|l|l|l|l|}
\hline \multirow{2}{*}{ Growth parameters } & \multirow{2}{*}{ Control } & \multicolumn{3}{c|}{ \% lipid in the diet } \\
\cline { 3 - 5 } & & \multicolumn{1}{c|}{$\mathbf{3 \%}$} & $\mathbf{6 \%}$ & \multicolumn{1}{c|}{$\mathbf{9 \%}$} \\
\hline No. of fish / aquarium & 15 & 15 & 15 & 15 \\
\hline Initial average weight (g) & $25.67^{\mathrm{a}}$ & $25.67^{\mathrm{a}}$ & $25.67^{\mathrm{a}}$ & $25.67^{\mathrm{a}}$ \\
\hline Final average weight (g) & $47.25^{\mathrm{b}}$ & $48.70^{\mathrm{b}}$ & $41.10^{\mathrm{c}}$ & $54.35^{\mathrm{a}}$ \\
\hline Weight gain (g) & $21.58^{\mathrm{b}}$ & $23.03^{\mathrm{a}}$ & $15.43^{\mathrm{c}}$ & $28.68^{\mathrm{a}}$ \\
\hline \% weight gain & $84.07^{\mathrm{b}}$ & $89.72^{\mathrm{a}}$ & $60.11^{\mathrm{c}}$ & $111.73^{\mathrm{a}}$ \\
\hline Average daily gain/fish & $0.22^{\mathrm{b}}$ & $0.24^{\mathrm{b}}$ & $0.16^{\mathrm{c}}$ & $0.29^{\mathrm{a}}$ \\
\hline Survival \% & 100 & 100 & 100 & 100 \\
\hline Specific growth rate \% & $0.64^{\mathrm{b}}$ & $0.66^{\mathrm{b}}$ & $0.49^{\mathrm{c}}$ & $0.78^{\mathrm{a}}$ \\
\hline Feed conversion ratio & $2.4^{\mathrm{a}}$ & $2.4^{\mathrm{a}}$ & $2.39^{\mathrm{a}}$ & $2.39^{\mathrm{a}}$ \\
\hline Protein efficiency ratio & $1.65^{\mathrm{b}}$ & $1.66^{\mathrm{b}}$ & $1.68^{\mathrm{ab}}$ & $1.70^{\mathrm{a}}$ \\
\hline Feed consumed /fish / day & $51.8^{\mathrm{b}}$ & $55.8^{\mathrm{b}}$ & $37.0^{\mathrm{c}}$ & $68.8^{\mathrm{a}}$ \\
\hline Initial average length /fish (Cm) & 11.1 & 1101 & 11.1 & 11.1 \\
\hline Final average length / fish (Cm ) & 14.8 & 13.8 & 13.8 & 13.2 \\
\hline
\end{tabular}

The same trend was observed with \% weight gain, when fish fed on $9 \%$ fish oil diet recorded the highest value (111.7\%) followed in a significant $(\mathrm{P}<0.05)$ decreasing order by control and 6\% oil groups respectively, however differences among the 9 and 3\% oil groups were insignificant.

The specific growth rate (SGR) increased with increase of the lipid level showing its maximum value of 0.78 in fish fed at $9 \%$ except at the $6 \%$, that reached to the lowest value 0.49, there was on significant difference in SGR for fish fed at the $3 \%$ control diet but fish fed at $6 \%$ and $9 \%$ showed significant difference between these groups .Feed conversion ratio (FCR) showed the same values of about 2.4, with no significant difference between fish fed on the 3\%, 6\% and $9 \%$ lipid and the control. 
Also the protein efficiency ratio varied between 1.65 and 1.70 , with no significant difference in fish fed the three levels of lipids. Protein efficiency ratio (PER) and feed conversion ratio (FCR) are shown in Table (3). Results for PER show that group fed the $9 \%$ supplemented oil show higher PER value $(\mathrm{P}<0.05)$ compared to the control and the $3 \%$ oil groups, however differences in this trail among the control, 3 and $6 \%$ oil supplemented groups, were insignificant, whereas FCR showed no significant difference among all treatment (2.4). Chemical analysis of fish whole body are shown in Table (4). Moisture content was not significantly different ( $>0.05)$ among all experimental treatment and control diet. The highest value of protein content was obtained with fish fed diets $(6 \%, 3 \%)$ supplemented oil and control diet compared to the 9\% oil group. There was no significant differences $(\mathrm{p}>0.05)$ in protein content between fish fed control diet and diet containing 3\%lipid and 6\%lipid (55.0to55.2). While fish fed 9\% lipid showed significant decrease in body protein content $(\mathrm{p}<0.05)$ (45.94).Concerning lipid contents in whole fish body, results of Table (4) revealed that fish fed on $9 \%$ oil diet showed significantly $(\mathrm{P}<0.05)$ the highest records compared to the other dietary treatment groups.

Table 4: Chemical composition of whole fish body of Oreochromis niloticus after16week rearing period (dry weight).

\begin{tabular}{|c|c|c|c|c|}
\hline Item & Control & $3 \%$ lipid & $6 \%$ lipid & $9 \%$ lipid \\
\hline Moisture & $72.54 \pm 0.4^{\mathrm{a}}$ & $72.1 \pm 0.3^{\mathrm{a}}$ & $73.01 \pm 0.6^{\mathrm{a}}$ & $72.95 \pm 0.5^{\mathrm{a}}$ \\
\hline Crude protein & $54.25 \pm 0.2^{\mathrm{a}}$ & $55.0 \pm 0.1^{\mathrm{a}}$ & $55.13 \pm 0.1^{\mathrm{a}}$ & $45.94 \pm 0.3^{\mathrm{b}}$ \\
\hline Crude lipid & $23.49 \pm 0.1^{\mathrm{a}}$ & $23.5 \pm 0.2^{\mathrm{a}}$ & $23.81 \pm 0.2^{\mathrm{a}}$ & $25.69 \pm 0.3^{\mathrm{b}}$ \\
\hline Crude ash & $22.32 \pm 0.2^{\mathrm{a}}$ & $21.2 \pm 0.1^{\mathrm{a}}$ & $20.48 \pm 0.2^{\mathrm{b}}$ & $20.26 \pm 0.3^{\mathrm{b}}$ \\
\hline
\end{tabular}

Values are mean in same row with same superscripts are not significantly different $(\mathrm{p}>0.05)$.

Ash content almost showed similar value of $21.2 \pm 0.1,20.5 \pm 0.2$ and $20.26 \pm 0.3 \%$ for the three tested diets respectively whereas fish fed on control diet ash content had $22.3 \pm 0.2 \%$.

The effect of different levels of lipids on some haematological parameters of Oreochromis niloticus are shown in Table (5) and Figs. (1, 2).

Table 5: Changes in some haematological parameters and serum analysis of Oreochromis niloticus at the end of the experiment.

\begin{tabular}{|l|c|l|l|l|}
\hline \multirow{2}{*}{ Parameter } & \multicolumn{3}{c|}{ Level of lipid supplement \% } \\
\cline { 2 - 5 } & \multicolumn{1}{|c|}{$\mathbf{0}$} & $\mathbf{3}$ & $\mathbf{6}$ & \multicolumn{1}{c|}{$\mathbf{9}$} \\
\hline Erythrocyte counts $\left(10^{6} / \mathrm{mm}^{3}\right)$ & $2.40 \pm 0.12^{\mathrm{a}}$ & $2.61 \pm 0.1^{\mathrm{a}}$ & $2.62 \pm 0.11^{\mathrm{a}}$ & $2.47 \pm 0.26^{\mathrm{a}}$ \\
\hline Haemoglobin content $(\mathrm{gm} / 100 \mathrm{ml}$ blood) & $9.59 \pm 0.46^{\mathrm{c}}$ & $9.98 \pm 0.2^{\mathrm{bc}}$ & $10.58 \pm 0.54^{\mathrm{ab}}$ & $10.9 \pm 0.9^{\mathrm{a}}$ \\
\hline Haematocrit value $(\%)$ & $20.48 \pm 1.24^{\mathrm{b}}$ & $22.72 \pm 0.65^{\mathrm{a}}$ & $23.4 \pm 1.21^{\mathrm{a}}$ & $18.84 \pm 0.85$ \\
\hline Total leucocyte counts $\left(10^{3} / \mathrm{mm}^{3}\right)$ & $4.37 \pm 0.29^{\mathrm{c}}$ & $4.77 \pm 0.23^{\mathrm{b}}$ & $4.74 \pm 0.29^{\mathrm{b}}$ & $5.16 \pm 0.23^{\mathrm{a}}$ \\
\hline Total protein (TSP ) (gm/100ml serum) & $4.80 \pm 0.25^{\mathrm{bc}}$ & $5.22 \pm 0.26^{\mathrm{a}}$ & $4.60 \pm 0.16^{\mathrm{c}}$ & $4.96 \pm 0.23^{\mathrm{ab}}$ \\
\hline Albumin (TSA) & $0.46 \pm 0.03^{\mathrm{b}}$ & $0.49 \pm 0.03^{\mathrm{ab}}$ & $0.52 \pm 0.03^{\mathrm{a}}$ & $0.31 \pm 0.04^{\mathrm{c}}$ \\
\hline Globulin (TSG) & $4.34 \pm 0.25^{\mathrm{bc}}$ & $4.72 \pm 0.27^{\mathrm{a}}$ & $4.08 \pm 0.18^{\mathrm{c}}$ & $4.65 \pm 0.24^{\mathrm{ab}}$ \\
\hline Albumin / Globulin ratio & $0.11 \pm 0.01^{\mathrm{b}}$ & $0.11 \pm 0.01^{\mathrm{b}}$ & $0.13 \pm 0.013^{\mathrm{a}}$ & $0.07 \pm .01^{\mathrm{c}}$ \\
\hline Glucose (mg / 100ml ) & $36.06 \pm 1.43^{\mathrm{d}}$ & $39.38 \pm 1.32^{\mathrm{c}}$ & $45.02 \pm 0.87^{\mathrm{b}}$ & $49.28 \pm 1.17^{\mathrm{a}}$ \\
\hline Cholesterol (mg/100ml ) & $96.0 \pm 1.43^{\mathrm{d}}$ & $75.94 \pm 1.33^{\mathrm{c}}$ & $87.74 \pm 1.9^{\mathrm{b}}$ & $96.7 \pm 4.63^{\mathrm{a}}$ \\
\hline
\end{tabular}

Mean in the same row bearing different superscript letters differ significantly at $\mathrm{p}=0.05$ level. 
Fig. 1: Changes in some haematological parameters and serum analysis of Oreochromis niloticus at the end of the experiment.

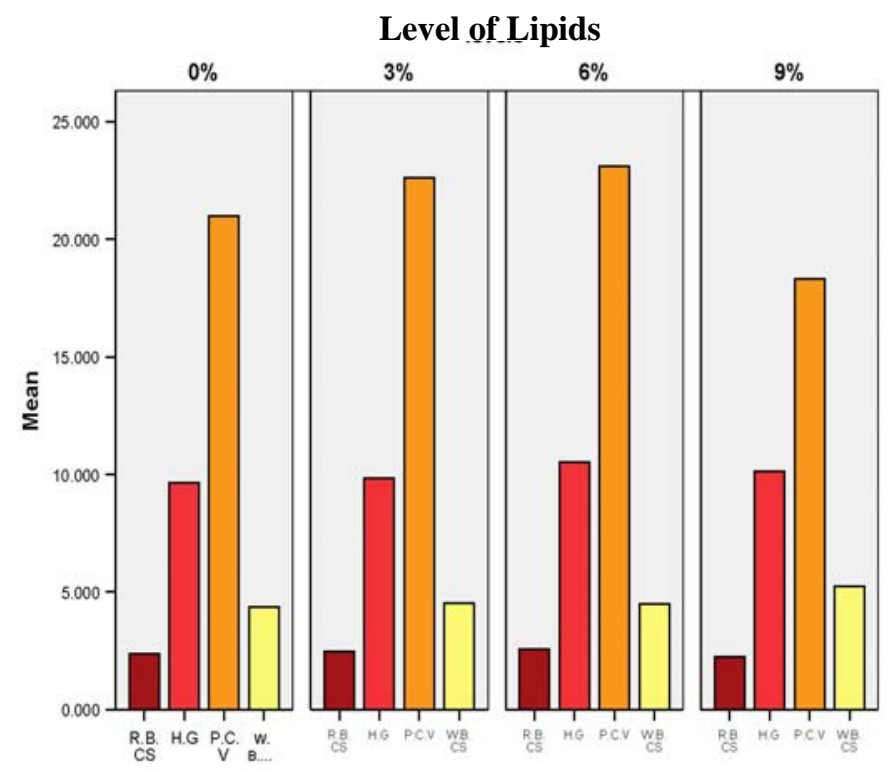

Fig. 2: Changes in some haematological parameters and serum analysis of Oreochromis niloticus at the end of the experiment.

\section{Level of Lipids}

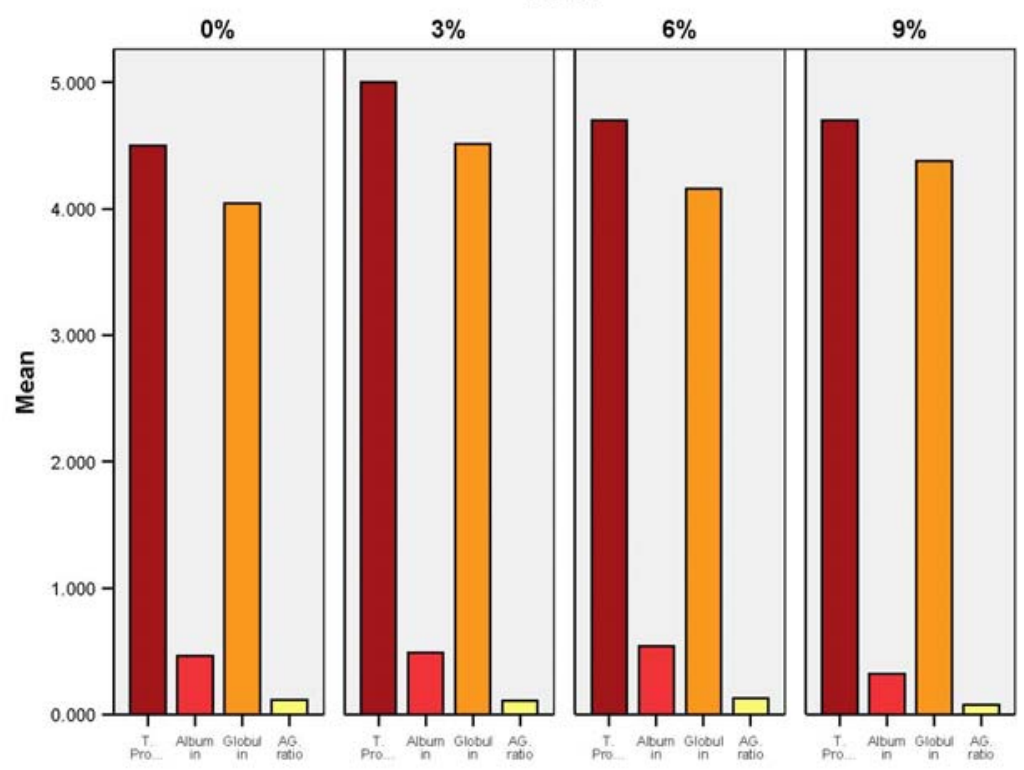




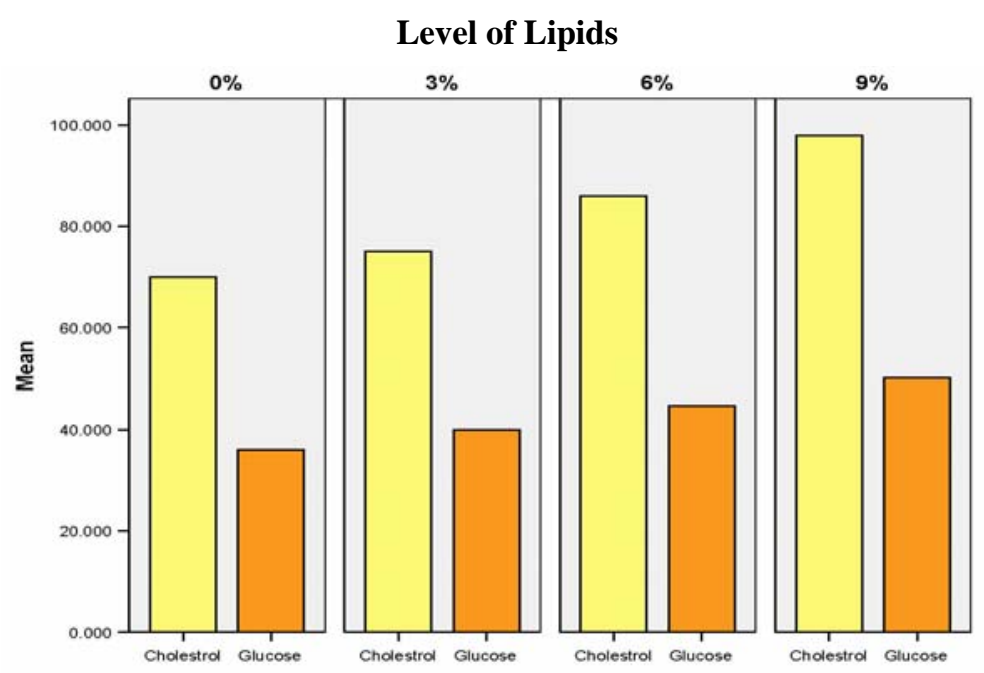

Haemoglobin content was significantly $(\mathrm{p}<0.05)$ affected by the levels of lipid, being higher for the fish maintained on diets containing $6 \%$ and $9 \%$ lipid supplement. Serum glucose as an indicator of fish metabolic rate increased also significantly $(\mathrm{p}<0.05)$ with the increase of lipid levels $(39.3 \pm 1.32,45.02 \pm 0.87$ and $49.9 \pm 1.17 \mathrm{mg} / 100 \mathrm{ml}$ ) for the 3,6 and $9 \%$ oil groups respectively.

In the present study, cholesterol values increased significantly $(\mathrm{p}<0.01)$ with increasing the levels of lipid $(75.9 \pm 1.33,87.7 \pm 1.9$ and $96.7 \pm 4.63 \mathrm{mg} / 100$ $\mathrm{ml}$ ), respectively. On the other hand, the concentrations of protein as well as albumin in the serum of Nile tilapia changed insignificantly.

\section{DISCUSSION}

One of the challenges that face fish nutritionists is to spare the expensive dietary protein with inexpensive non-protein energy source such as lipid. Lipid must be included in fish diets at levels that maximize the use of protein for growth (EL-Sayed and Garling, 1988). Dietary lipids play an important role as a source of energy and essential fatty acids, and thus there is an interest in determining the optimal amount of dietary lipid for maximum growth in fish. Dietary lipid plays an important role in providing a source of concentrated energy, essential fatty acids (EFA) and some fat-soluble vitamins for fish (Mai et al., 1995) .However, the use of lipid in fish diets must be closely evaluated because excessive lipid may be disadvantageous to the pelleting quality of food, growth of fish and shelf- life of fish products (Jauncey, 1982).

Hepher and pruginin (1982) showed that tilapia in order to grow at their potential rate require food that will sustain them and provide nutrients for their growth. Also, Siddiqui et al. (1988) found that growth of Oreochromis niloticus 
was decrease with using diets containing 8\% Lipid. The increase of dietary lipid should be carefully considered as it may affect carcass quality, mainly due to an increase in lipid deposition (Hillestad and Johnsen, 1994).

Meanwhile, Labib et al. (1995) showed that the Oreochromis niloticus fed on diets containing 28\% protein and three levels of fat (3, 6 and $9 \%$ ) showed increases in weight from 12.6 to $169.3 \mathrm{~g}$, from 10.6 to 154.39 and from 10.0 to 164.1g respectively. Kheir (1997) indicated that Oreochromis aureus fingerlings attained its highest growth with diets containing 6\% lipid, then decreased in fish fed on diet with $8 \%$ dietary lipid.

This may indicate that excessive lipid may restrict protein consumption and consequently retard the growth. On the other hand, it seems that the $6 \%$ dietary lipid level improved digestion and absorption of nutrients. Several factors such as dietary protein and lipid levels, fish species and feeding regime may affect the utilization of dietary lipid in fish. From the present results, it is obvious that, Oreochromis niloticus attained higher growth when a diet containing 9\% supplemented lipid was used than in case of using diets containing 3\% and 6\% supplemented lipid.

Similar levels of dietary lipid were mentioned by many authors on feeding tilapia species; Hassanen (1988) stated that the dietary fat when increased from 3 to $6 \%$ of the diet appeared to spare protein as reflected in greater protein deposition with higher fat level.

Willams and Robinson (1988) summarized the importance of lipid as one of the main food items is due to the fact that it provides a source of concentrated energy and essential fatty acids, and can be used to spare dietary protein for growth .Lipids also can be used as a source of protein- sparing energy (Brandt,1979). The importance of lipids as a main source of energy was studied by many authors (Halver, 1976 Winfree and Stickney, 1981 and Viola et al., 1988). Replacing dietary protein with lipid improved the growth and PER of Atlantic salmon when the diets were administered isonitrogenously (Hillestad and Johnsen, 1994) .Improvement of growth and PER with increasing dietary energy level at constant dietary protein level was found for rainbow trout (Beamish and Medland, 1986) and white sea bass (Lopez et al., 2009).

The present results showed that the percentage weight gain increased with the increase in supplemented lipid attaining the highest value, $111.73 \%$ in fish fed on diet with 9\% lipid. This confirms the finding of Saad, (1995) who showed that the percentage weight gain for Oreochromis niloticus increased with the increase of dietary lipid. The specific growth rate (SGR) showed its minimum value $(0.49 \%)$ in fish fed on feed with 6\% lipid. This result agrees with the finding of Siddiqui et al. (1988) who showed that specific growth rate (SGR) of Oreochromis nilloticus decreased with diets containing 8\% Lipid. The food conversion ratio showed (2.4\%) g. feed for each g. gain in weight in fish fed on feed with 3\%, 6\% and 9\% lipid. Also there was no significant differences in protein efficiency ratio (PER) for the three treatments, which was similar to the 
results of Hassanen (1987) who indicated that PER was improved significantly as the crude protein in the diet decreased, but did not improved significantly with the increase of the oil supplement. Chatzifotis et al. (2010) reported that, the serum metabolites did not show significant differences among the three dietary lipid levels of meager (Argyrosomsu regius) juveniles. They also found that the daily feed intake was not affected by the dietary lipid level, but there were significant differences in feed conversion ratio and protein efficiency ratio.

Biochemical analysis of whole fish body of Oreochromis niloticus showed that the protein content increased with increasing supplemented oil. These results confirm the results obtained by Kheir (1997) who found the highest protein content in muscles of Oreochromis aureus was recorded with 6\% lipid, that pointed also out that protein content decreased more than $6 \%$ with lipid levels. Furthermore, the present results showed that lipid content in fish whole body also increased progressively as dietary lipid increased confirming the results obtained by Bayoumi (1987) on Oreochromis niloticus. Further more Tibaldi et al. (1996) found an inverse relationship between water and lipid content and a positive correlation between dietary lipid and body lipid. Also Abdel-Hakim et al. (2008) on Oreochromis niloticus showed the same results.

Also Samra (2002) found that increasing dietary protein level from 2 to 25 and $30 \%$ significantly increased both moisture and protein contents in Nile tilapia flesh. Li, et al. (2010) recorded that, the moisture content, lipid content of whole body and carcass of blunt shout bream (Megablorama amblycephala) increased significantly $(\mathrm{p}<0.05)$ with increasing dietary lipid levels from $4 \%$ to $7 \%$ and $10 \%$.

Tabachek (1986) Stated that when dietary lipid was too high, the excess lipid was deposited within body tissues. Williams and Robinson (1988) reported that body lipid was increased with increased dietary lipid. Siddiqui et al. (1988) stated that there was an inverse relationship between water content and lipid content of Oreochromis niloticus fry. The same authors noticed that the body protein content increased with increasing the protein levels in the diet.

The most prominent feature of the physiological response of Nile tilapia (Oreochromis niloticus) fed with different levels of lipid inclusions was a significant increase in cholesterol level with increasing diet lipid. This extreme variability no doubt reflects on dietary input, which contains more level of lipid.

Barnhardt (1969) showed that soybean meal raised cholesterol levels of rainbow trout beyond those in fish fed on other diets. Haemoglobin content for Nile tilapia was significantly higher in fish maintained on diets containing $6 \%$ and $9 \%$ lipid supplement.

Decreasing of haemoglobin in other diets might be ascribed to a decrease in the general condition of the fish or a deficiency in some essential fatty acid (Castell et al., 1972). Kikuchi et al. (2009) mentioned that the tiger puffer Takifugu rubripes showed best growth rates when fed on diet containing 5.9, 11.0 and $16.3 \%$ lipid compared with the other levels (21.4 and 25.7\%). Also 
they observed that the haemoglobin decreased but glucose increased with increasing lipid level and other parameters were independent of dietary composition.

The increase of serum glucose levels as an indicator of fish metabolic rate with increasing lipid levels may be due to the increased metabolic requirement of the fish of decreased metabolic turnover rate. Glucose is a stress indicator (Rotllant and Tort, 1997 and Pottinger,1998), but it is also affected by other factors such as temperature, fish size (Hemre and Sandnes,1999), photoperiod and the time passed from last feeding (Pavlidis et al., 1999) and the diet, as Hemre et al., (1996) observed that glucose increases with the increase of starch in the diet.

Chatzifotis et al. (2010) showed that cholesterol; triglycerides and total protein in meager blood were not affected by the different levels of lipid (13, 17 and 21\%). In contrast, the increase of the above metabolites due to the increase in dietary fat was reported for grass carp (Du et al., 2005) and Atlantic salmon (Salmo salar, L.) (Hamre et al., 2004) which seem to have the lower values of total proteins, (5.4-6.1g/ dl) and much higher values of cholesterol, (11.1-14.6 mmol /l.). Undesirable effects of increasing dietary lipid on triglyceride and protein levels were also reported for Japanese flounder and cobia (Craig et al., 2006). Positive effects of dietary lipid on muscle lipid level were reported for Atlantic salmon, cobia, and White Sea bass (Lopez et al., 2009). Based on the obtained results, it could be concluded that an artificial feed with $3 \%$ and $9 \%$ supplemented fish oil is sufficient for feeding $O$. niloticus without any adverse effects on growth performance, body composition and haematological properties.

\section{REFERENCES}

Abdel-Hakim, N. F.; Lashin, M.E.; Al-Azab, A.A. and Nazmi, H.M. (2008). Effects of replacing soybean meal with other plant protein sources on protein and energy utilization and carcass composition of Nile tilapia (Oreochromis niloticus). Inter. $8^{\text {th }}$ Symposium on tilapia in Aquacult., 979997.

Abdel-Tawwab, M.; Ahmed, M.H.; Khattab, Y.A.E. and Shalaby, A.M.E. (2010). Effect of dietary protein level , initial body weight, and their interaction on the growth, feed utilization ,and physiological alterations of Nile tilapia, Oreochromis niloticus (L.). Aquacult., 298:267-274.

Barnhardt, A. (1969). Effects of certain variables on hematological Characteristics of rainbow trout .Trans .Am .Fish .Soc. 3:411 -418.

Bayoumi , A.R. (1987). Development of fish farming in Egypt cage culture. Academy of Scientific Research and Technology, Institute of 
Oceanography and Fisheries, Cairo, Egypt and IDRC. Canada. Rep .No .5 (Phase II), 63 PP.

Beamish , H.W.F. and Medland , E.T. (1986) .Protein sparing effects in large rainbow trout, Salmo gairdneri .Aquaculture 55, pp, 35- 42.

Brandt, T.M .(1979). Use of feat treated full fat soybeans in channel catfish and golden shiner feeds. Texas Fish Farming Conf, January, 1979.

Castell . J.; Sinnhber, R.; Wales, J. and Lee, J. (1972). Essential fatty acids in the diet of rainbow trout, Salmo gairdneri .Physiological Symptoms of EFA deficiency. J. Nutr., 102:87-92.

Chatzifotis, S.; Panagiotidou, M.; Papaioannou, N.; Pavlidis, M; Nengas, L. and Mylonas, C. (2010). Effect of dietary Lipid levels on growth, feed utilization, body composition and serum metabolites of meagre (Argyrosomus regius) Juveniles. Aquacult., V. 307: 65-70.

Craig, R.S.; Schwarz, H.M. and Mclean, E. (2006). Juvenile cobia (Rachycentron conadum) can utilize a wide range of protein and lipid levels without impacts on production characteristics. Aquacult., 261, pp. 384-391.

Dato-Cajegas, C.R.S. and Yakupityage, A. (1996). The need for dietary mineral supplementation for Nile tilapia Oreochromis niloticus cultured in a semiintensive system. Aquacult., 144: 227-237.

DU, Z.Y.; Liu, J.Y.; Tian, X.L.; Wang, T.J.; Wong , Y . and Liang, Y.G.(2005). Effect of diteray lipid level on growth, feed utilization and body composition by juvenile grass carp (Ctenofparyngodon idella), Aquacult. Nutrit. (pp.139-146).

El-Sayed, A. and Garling, D. (1988). Carbohydrate to lipid ratios in diets for Tilapia zillii fingerlings . Aquacult., 73:157-163

FAO, (1997). Food and Agriculture Organization ' Aquaculture Production Statistics, 1986-1995. FAO Fish .Cire No. 815 Rev .9Rome, Italy.

GAFRED (Gen. Auth. Fish .Res. Develop. Egypt) (1996) .Annual report for country fish production in 1996.

Halver, J.E. (1976):Formulating practical for fish. J. Fish Res. Bd. Can., 33: $1032-1039$. 
Hamre, K.; Christansen, R.; Waagbo, R.; Maage, A .; Torstensen , E .B.; Lygren, B.; Lie, Q.; Wathne, E. and Albrektsen, S. (2004). Antioxidant vitamins, minerals and lipid levels in diets for Atlantic salmon (Samo salar, L.): effect on growth performance and fillet equality, Aquacult., Nutrition 10:113-123.

Hassanen, G.D.I. (1987). Feeding experiments on the Nile catfish, Clarias lazera (C \& V) reared in cages. Proc .Zool .Soc . A. R .E.,14: 155-168.

Hassanen, G. D. I. (1988). Influence of cotton seed oil on growth of Tilapia nilotica reared in cages. Proc. Z001.Soc. A. R .Egypt, V. (16): 239-248.

Hemre, I .G.; Hjertens, B.; Aksnes, A. and Waagbo, R .(1996) .Effect of gelatinized wheat and maize in diets for large Atlantic salmon (Salmo salar L.) on glycogen retention, Plasmaglucose, and fish health. Aquacult. Nutrit. (1996), pp. 33-39.

Hemre, I.G. and Sandenes, K. (1999). Effect of dietary lipid level on muscle composition in Atlantic salmon Salmo salar. Aquacult. Nutrit., 5 (1999), pp. 9-16.

Hepher, B. and Pruginin, Y. (1982).Commercial fish farming with special references of fish farming culture in Israel. John Wiley and Sons, N.Y., USA, 216 pp.

Hillestad , M. and Johnsen, F.T. (1994). High - energy / low - protein diets for Atlantic salmon (Salmo salar), effects on growth, nutrient retention and sloughter quality. Aquacult.124 (1994), pp. 109-116.

Jauncey. K. (1982). The effects of dietary protein level on the growth, food conversion, protein utilization and body composition of juvenile tilapia (Sarotherodon mossambicus). Aquacult. 27:34-56.

Kheir, M.T. (1997). Growth of caged Oreochromis auraus (Steindachner, 1864) raised on artificial feeds with different levels of lipids. Egypt. J. Z001. V (28): 77- 86.

Kheir, M.T. (1997). Growth of Oreochromis niloticus (Linnaeus, 1757) raised on feeds with different protein levels. Egypt J. Zool., 28: 65-76.

Kikuchi, K.; Furuta, T.; Iwala, N.; Onuki, K. and Noguchi, T. (2009): Effect of dietary lipid levels on the growth, feed utilization, body composition and 
blood characteristics of tiger puffer Takifugu rubripes. Aquacult., V.298 :111-117.

Kim, O. L. and Lee, M. S. (2005). Effect of dietary protein and lipid levels on growth and body composition of begird catfish, Pseudobagrus fulvidraco. Aquacult., 243: 323-329.

Kowalska, A.; Zakes, Z.; Jakowska, B.and Siwicki, A. (2010). Impact of diets with vegetable oils on the growth, histological structure of internal organs, biochemical blood parameters, and proximate composition of pikeperch Sander iucioperca (L.). Aquacult., 301:69-77.

Labib, W.; Shahat, T; kheir, M.T. and Sobhy, A. S. (1995). Growth of tilapia nilotica (Oreochromis niloticus ) fed with feed of different levels of lipids , Bull Fac . Sci ., Zagazig Univ., V .17(1):166-180.

Li, X-F; Liu, W-B.; Jiang, Y-Y.; Zhu, H. and Ge, X. P. (2010). Effects of dietary protein and lipid levels in practical diets on growth performance and body composition of blunt snout bream (Megalobrama amblycephala) fingerlings, V .303: 65-70.

Lopez, M. L.; Durazo, E.; Viana, T.M.; Drawbrige, M. and Bureau, P. D. (2009). Effect of dietary lipid levels on performance, body composition and fatty acid profile of juvenile white seabass, Atractoscion nobilis. Aquacult., 289: 101-105.

Lovell, R. (1989). Nutrition and Feeding of Fish .Auburn University. Van Nostrand Reinhold, New York.

Mai, K.S.; Mercer, J. P. and Donlon , J. (1995). Comparative studies on the nutrition of two species of abalone, Haliotis tuberculata L. and Haliotis discushannar II. Response of abalone to various levels of dietary lipid . Aquacult., 134:65-80.

National Research Council (NRC), (1993). Nutrient Requirements Fishes, National Academy Press, Washington, De. 114 pp

New, M.B. and Wijkstrom, U.N. (2002). Use of fish meal and fish oil in aqua feeds: Further thoughts on the fish meal. Trop, FAO Fisheries Circular (975 FIPP/C 975), FAO, Rome Italy, pp. 61

Ng, K.W.; Sigholt, T.and Bell, G.T. (2004 a). The influence of environmental temperature on the apparent nutrient and fatty acid digestibility in Atlantic 
salmon (Salmo salar L.) fed finishing diets containing different blends of fish oil, rapeseed oil and palm oil. Aquacult., Res . 35:1228-1237.

Parazo, M.M. (1990). Effect of dietary protein and energy level on growth, protein utilization and carcass composition of rabbit fish Siganus quttatus. Aquacult ., 86:41-49.

Pavlidis, M., Paspatis, M.; koistinen, M.; Paavola, T., Divanach, P. and kentouri, M. (1999) .Deil rhythms of serum metabolites and thyroid hormones in red porgy held in different photoperiod regimes. Aquacult., International 7:29-44 .

Pottinger, G .T. (1998). Changes in blood cortisol glucose and lactate in carp retained in angler's Keepnets . Journal of Fish Biology 53:728- 742.

Pratoomyot, J.; Bendiksen, E.A.; Bell, J.G. and Tocher, D.R.(2010).Effects of increasing replacement of dietary fishmeal with plant protein sources on growth performance and body lipid composition of Atlantic salmon (Salmo salar L.). Aquacult., 305:124-132.

Richardson, N.I.; Higgs, A.D.; Beames, M.R.and McBride, R.J. (1985). Influence of dietary calcium, phosphorus, zinc and sodium phytate levels on cataract incidence, growth and histopathology in juvenile Chinook salmon, Oncorhynchus tshayvytscha. Journal of Nutrition 115:553-567.

Rotllants, J.and Tort, L. (1997). Cortisol and glucose responses after acute stress by net handling in the sparidred porgy previously subjected to crowding stress. Journal of Fish Biology 51:21-28.

Saad, A.S. (1995). Effect of dietary lipids on growth, biochemical composition of the flesh and gonad development of Tilapia nilotica M.Sc. Thesis, Fac .Sci., Monoufia Univ., 130 pp.

Samra, I.M. (2002). Some factors affecting protein requirements for tilapia fish. M.Sc. Thesis, Fac. Agric., Moshtohor, Zagazig University (Benha Branch).

Santiago, C.B. and Reyes, O.F. (1993). Effects of dietary lipid source on reproductive performance and tissue lipid levels of Nile tilapia Oreochromis niloticus (Linnaeus) broodstock. J. Appl. Ichthyol. 9: 33-40.

Sendecor, G.W. and Cochran, W.G.(1982).Statistical Method of Analysis $6^{\text {th }}$ ed. Iowa State Univ. Press Amer.Iowa, USA, 593pp. 
Siddiqui, A. Q.; Howlader, M.S. and Adam A.A. (1988). Effects of dietary protein levels on growth, fed conversion and protein utilization in fry and young Nile Tilapia, Oreochromis niloticus. Aquacult., 70: 63-73.

Tabachek, J.L. (1986). Influence of dietary protein and lipid levels on growth, body composition and utilization efficiencies of Arctic charr, Salvelinus alpinus L .J.Fish .Biol , 29:139-151.

Tacon, A.G. J. (1993). Feed ingredients for warm water fish. Fish meal and other processed feed stuffs .FAO Fish Cir., 856, FAO, Rome, Italy, 64 pp.

Takii, K.; Ukawa, M.; Nakamura, M. and Kumai, H. (1995 b). Suitable lipid level in brown fish meal diet for tiger puffer fish. Fish Sci . 61:841-844.

Tibaldi, E.; beraldo, p.; Volpelli, L. A. and Prionsa, M. (1996). Growth response of juvenile dentex (Dentex dentex L.) to varying protein level ration in practical diets. Aquacult., 139:91 -99.

Viola , S., Arieli, Y .and Zohar, G. (1988) : Unusual feedstuffs (Lopioca And lupin) as ingredients for carp and tilapia feeds in intensive culture. Bamidgeh, 41:29-34.

Williams, C.D. and Robinson, E.H. (1988). Response of red drum to Various dietary levels of Menhaden oil. Aquacult ., 70:107-120.

Winfree , R.A. and Stickney , R.R (1981). Effects of dietary protein and energy on growth, food conversion efficiency and body composition of Tilapia aurea. J. Nutri , 111: 1001-1012.

Xie, S.; Cui, Y.; Yang, Y .and Liu, J. (1997) .Effect of body size on growth and energy budget of Nile tilapia Oreochromis niloticus . Aquacult., 157:2534.

Zheng, K.; Zhu, X.; Han, D.; Yang, Y.; Lei, W. and Xie, S.(2010). Effects of dietary lipid levels on growth, survival and lipid metabolism during early ontogeny of Pelteobagrus vachelli larvae. Aquacult. 299:121-127. 